\title{
A new phase in the journal's history
}

\author{
J. Smit, Th.E. Wong, C. Kasse \& A.J. van Loon
}

You may have been aware that Geologie en Mijnbouw, the journal of the Royal Geological and Mining Society of the Netherlands (KNGMG), would be rejuvenated. This new phase has started with the present issue, and brings many changes; for the publisher, the editors, the authors, the subscribers and - last but not least - the readers. Much can be said about these changes, but we mention here only the most important ones; we sollicit comments from all those interested in the transfer of geological information.

\section{A new publisher}

Geologie en Mijnbouw was, for many decades, published by the KNGMG. Starting with volume 64 (1985), the journal was published by Martinus Nijhoff Publishers, which company formed part of the Kluwer Academic Publishers Group; Kluwer continued the publication later by Kluwer Academic Publishers. The objective was, obviously, that the professional publishing company would help the journal to grow, to attract more authors, subscribers and readers, and to improve the technical and scientific level further, at lower cost. This objective was, unfortunately, not reached. The publication time increased, the subscription price increased considerably, the number of subscribers decreased steadily, and costs for the KNGMG became prohibitive.

Action had therefore to be taken, and the KNGMG decided to search a new basis for publication. One of the possibilities that soon surfaced was a merger with the Mededelingen Nederlands Instituut voor Toegepaste Geowetenschappen - TNO, which was published by the successor of the Geological Survey of the Netherlands (Rijks Geologische Dienst), the Netherlands Institute of Applied Geoscience - TNO (NITG-TNO). Both journals have merged indeed, and the new, combined, journal is now published by a foundation established jointly by the KNGMG and NITG-TNO. The foun- dation (Stichting Netherlands fournal of Geosciences) is a joint venture ( $50 \%$ both).

The foundation decided to emphasize the new character of the journal by a slight change in its name, because the original title of Geologie en Mijnbouw was difficult to understand - and even more difficult to pronounce - by the international readership. As you will have noticed on the front cover, the new titel is: Geologie en Mijnbouw / Netherlands Journal of Geosciences. The new journal will continue its volume numbering (volume 71 for the present year) and its International Standard Series Number (ISSN): 0016-7746.

\section{The authors as an indispensible factor}

Geologie en Mijnbouw contained articles about a wide variety of topics; too wide a variety, according to many readers. It was therefore decided to focus the rejuvenated journal on the North Sea Basin and geoscientifically relevant surrounding regions, including the North Atlantic. It is our intention to provide more reader-oriented contents, which fit in the daily work of the many researchers oriented on the Netherlands and the North Sea area.

Geosciences are not restricted to geology in its strict sense. We invite, obviously, manuscripts on purely geological topics, but we will also publish geotechnical, hydrogeological, geographical, archeological, numerical, petroleum geological, modelling and environment-oriented contributions with geoscientific aspects, subject to peer review.

The journal is thus envisaged to become one of the main scientific outlets for geologists working in the North Sea area and for the programs and projects of the NITG-TNO. We solicit input from the CLIVAR programme, devoted to research on land/sea correlations and postglacial climate fluctuations, and the Netherlands Earth Systems Dynamics Initiative 
(NEESDI). In view of the new scope of the journal, we will not consider for publication manuscripts that deal with geology from other areas, except for invited papers and contributions to special issues that, as a whole, are within our scientific focus.

It is our intention to publish special issues, as much as possible co-ordinated with the inflow of other manuscripts. Special issues that the editors currently try to realise include proceedings of (1) the 40 -year anniversary of the discovery of the Groningen gasfield, (2) the celebration of the 150-year Maastrichtian type locality, (3) the bi-annual Dutch Earth Science Congress, but also on topics such as the Eemian, and the Cretaceous/Tertiary boundary in Limburg. The editors invite other suggestions, which will be considered and scheduled to allow publication within a relatively short time.

We also expect to publish geoscientific background information on politically 'hot items', such as the various large infrastructural projects that are under debate (or being carried out) in the Netherlands, such as the 'green-heart rail tunnel', the North-South metro tunnel in Amsterdam, the 'Betuwe railway', an island in the North Sea to be built for a new airport, and the geoscientific aspects of drilling in the Wadden Sea.

The above topics should offer sufficient possibilities for all geoscientists working on or around the North Sea to publish their results in our journal. We invite all potential authors to read the inside cover of the journal carefully, and to adhere to the guide for authors at the end of the present issue. Manuscripts that are submitted in a form consistent with the guide, will have a short handling time.

\section{A promise to the subscribers}

We are well aware that the publication of Geologie en Mijnbouw has failed to meet common standards in the recent past. We sincerely apologize for these delays, that were due to factors beyond the control of the editors, such as extended handling by the previous publisher. We have moved now to a new printer (Veenman drukkers at Ede), and we expect that they are fully capable of keeping to a more acceptable time schedule. We promise therefore that unduly late publications will no longer frustrate our subscribers.

The journal will, for the time being, continue to be published in four issues per volume per year, including special issues. As mentioned above, we will maintain the ISSN and continue the volume numbering of Geologie en Mijnbouw, to stress the continuity of the journal. It has a respected scientific status in the ISI Science Citation Index, and Geologie en Mijnbouw I Netherlands Journal of Geosciences intends to keep and improve this status.

\section{What it's all about: the readers}

We invite the readers, like the authors, to read the various data on the inside cover. You will become aware that the journal has to offer more than the printed text because authors will be allowed to post additional material on the journal's website (http: //www.nitg.tno.nl/eng/products/pub/njg/index.shtml), which is still 'under construction'. The supplementary material can consist of lengthy tables, costly (colour) photographs, large coloured geological maps or seismic sections that will be referred to and linked to in the paper itself.

We thus hope to generate new enthusiastic response from both the Netherlands and the international readership; your comments, remarks and criticism are welcome, indeed! With your support, we will achieve a high international standard and we will serve you with timely, interesting and up-to-date geoscientific information. 